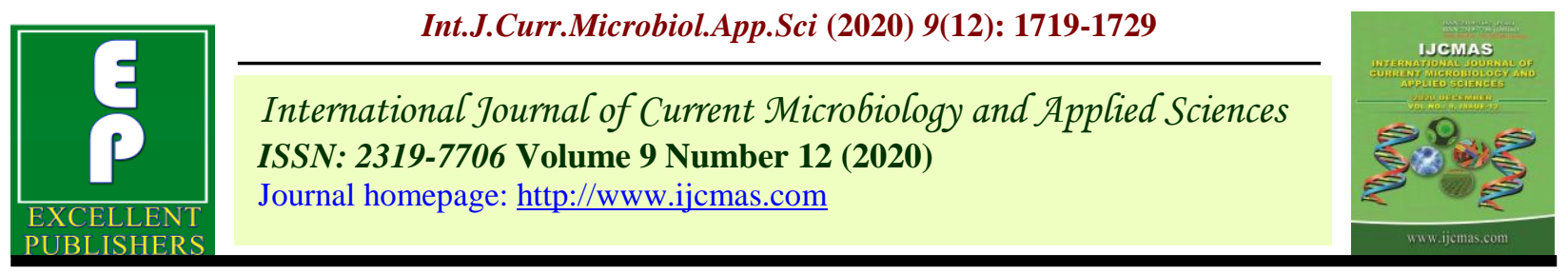

Original Research Article

https://doi.org/10.20546/ijcmas.2020.912.204

\title{
Farm Pond Impact Analysis of PMKSY-Watersheds Project in Srikakulam District of Andhra Pradesh
}

\author{
P.V.R.M. Reddy ${ }^{1}$, M. Girija Shankar ${ }^{2}$, B. Janardhan Reddy ${ }^{3}$, \\ Y. Shankar Naik ${ }^{4}$, Yerra Eswara Prasad ${ }^{5}$ and D.V.S.R.L. Rekha ${ }^{6 *}$
}

${ }^{1}$ Director (WS), ${ }^{2}$ IAS, Commissioner, ${ }^{3}$ Joint Commissioner (WS), ${ }^{4}$ State Technical Expert

(Forestry), CEO, SLNA, PR\&RD Department, Tadepalli, Andhra Pradesh, India

${ }^{5}$ Department of Agricultural Economics, ANGRAU, India

${ }^{6}$ WAPCOS Limited, Hyderabad, Telangana State., India

*Corresponding author

\begin{tabular}{l} 
Ke y w o r d s \\
$\begin{array}{l}\text { Crop diversification } \\
\text { index, Gini ratio, } \\
\text { Financial ratio }\end{array}$ \\
Article Info \\
$\begin{array}{l}\text { Accepted: } \\
\text { 14 November } 2020 \\
\text { Available Online: } \\
\text { 10 December } 2020\end{array}$ \\
\hline
\end{tabular}

\section{A B S T R A C T}

Crop Diversification Index (CDI), Income Inequalities and Economic Viability of farm ponds before and after situations of Batch III Pradhan Mantri Krishi Sinchai Yojana (PMKSY)-Watersheds in Srikakulam district (North-Coastal Zone) of Andhra Pradesh were assessed through Herfindahl - Hirschman Index, Giniconcentration Ratio and Discounted Financial Ratios respectively. The results indicated the changes in cropping pattern, resulting higher cropping intensity thus an increase of CDI during post-farm pond to 0.31 from 0.28 among the respondents due to the proper utilization of available water thus bringing additional area under cultivation. Further the decrease in Gini ratios from 0.31 to 0.22 revealed the significant existence of income distribution among the individual households from pre to post farm pond periods. Similarly, the economic viability and feasibility analyzed at $12 \%$ discount rate for a period of 10 years showed a positive NPW, 1.12 discounted BC ratio and IRR of 38\% which is higher than the bank interest rate with four (4) years of payback period which points out worthiness of farm pond construction in the study area. Thus, the farm pond activities may be encouraged to make the program more participatory interactive and cost-effective especially to small and medium farm categories.

\section{Introduction}

Water is the important critical and scarce input owing to erratic and uneven distribution of rainfall especially in dry land areas, there is a need to emphasize the conservation with suitable practices. Harvesting and recycling of rainwater in dry lands is important in order to improve water use efficiency (Shankar and Shivakumar, 2005). Moreover, rain water harvesting is an age-old practice followed by our ancestors since time immemorial. 
Keeping this in view the Department of Land Resources (DoLR) under the Ministry of Rural Development (MoD), Government of India has been implementing the PMKSYWatershed Programme since 2009. In Andhra Pradesh, the Department of Panchayat Raj \& Rural Development through the State Level Nodal Agency (SLNA) is implementing 372 watershed projects with an outlay of Rs.1985.16/- crores covering an extent of 15.83 lakh hectares in five batches from 2009-10 to 2013-14 with a more emphasize on rainwater harvesting and recharging of the groundwater in rainfed areas to achieve "more crop per drop". The productivity of rainfed crops can be significantly increased and protected if rainwater can be harvested and used to irrigate crops (Rao et al., 2010). Thus an important component of watershed development programme is harvesting of rainwater through farm pond which is a small water harvesting body made by either construction of embankment or excavating pit/dugout in the lowest point of the field where water tends to accumulate, thus excess water from the field can be stored and used in times of delayed monsoons as protective or lifesaving irrigation to the standing crops.

The initiative of farm ponds in scare rain fall areas has been a boon for marginal and small farmer categories, which are cost-effective. Though it looks like a simple structure, the intrinsic value of farm pond is multifaceted. Having identified the importance of farm pond in watershed project an attempt has been made to analyze the impact of farm ponds at the farm level in terms of:

(i) Crop diversification

(ii) Pattern of Income Distribution

(iii)Economic viability/profitability

at two periods of time i.e., Pre and Post construction/ dugout of farm ponds in the study area.

\section{Locale of the study area}

Srikakulam district of Andhra Pradesh was selected purposively as this is the only district in north coastal zone where Batch III (201112) projects of PMKSY-watershed has been in operation. Again, under Batch III only two projects Tarlakota and Ambugam with 8 and 13 micro-watersheds have been considered and those projects are on the verge of withdrawal phase. During the process of implementation of watershed activities in Tarlakota project area under creation of irrigation/ water storing structures 49 farm ponds have been constructed. Among these 40 farm ponds have completed more than 4 years of operation. Hence for the present study the data from these 40 households were collected by survey method with the help of specially designed pre-tested questionnaire through recall method for both pre and post periods of the construction of the farm ponds.

\section{Data collection}

Both primary and secondary data were collected in order to assess the impact of the farm ponds. The primary data on crops grown in kharif and rabi seasons, their productivity, costs and incomes were collected from the 40 ( $>80 \%$ of the total) selected households for "pre" and "post" farm pond situations in addition to secondary data from the office of the watershed committee.

\section{Methodology and statistical analysis}

In order to analyze the stated objectives, the following procedure and statistical tools in addition to t-test and coefficient of variation were adopted.

\section{Crop diversification index}

Crop diversification is a concept which is opposite to crop specializations. It is an 
indicator of multiplication of crops which obviously involves intense competition among the growing crops (Singh J. 1976). Crop diversification is generally viewed as a shift from traditionally grown less remunerative crops to more profitable crops. In order to find out the degree of crop diversification in the study region, the following Herfindahl index was employed to compare the diversification across situation having different and a large number of crops since it gives due weight to the number of crops grown.

$\mathrm{HI}=\sum_{\mathrm{i}=1}^{\mathrm{n}} \mathrm{Si}^{2}$

Where, $\mathrm{n}=$ number of crops

$\mathrm{S}(\mathrm{i}=1$ to $\mathrm{n})=$ Share of crops in total cropped area

Crops diversification is inversely related to the index.

\section{Pattern of income distribution}

The income of the selected households in the study area derived from different sources like agriculture, horticulture, dairy, wages etc., have been computed at two periods i.e., before and after digging of farm ponds. The income inequalities are measured among the households by Gini-coefficient ratio through Lorenz Curves. The shape of the Lorenz curve shows inequality in total incomes of the households.

\section{Lorenz curve}

The Lorenz curve is a tool used to represent income distribution as proposed by Lorenz (1905); it tells us which proportion of total income is in the hands of a given percentage of population. However, instead of ending up with income shares, the Lorenz Curve relates the cumulative proportion of individuals. The shape of the Lorenz curve is therefore a good visual indicator of how much inequality there is in an income distribution. Inequality measurement is an important factor that indicates weather benefits of the farm pond project have been concentrated on "trickled down" sufficiently to the community.

\section{Gini-concentration ratio - Gini Ratio}

The income inequalities are measured by Gini ratio or Gini concentration ratio and its value ranges from 0 to 1 , being ' 0 ' the value of perfect equality and 1 of maximum inequality. Another advantage of Gini co-efficient is that it can be easily represented in the Lorenz graph for a graphical as it represents the ratio of the difference between the line of absolute equality and the Lorenz Curve which represents the income distribution among the total households and it can be worked out as (Gowri and Shanmugam, 2017):

$\mathrm{G}=1+\left(\frac{1}{\mathrm{n}}\right)-\left(\frac{2}{\mathrm{n}^{\mathrm{z}} \mathrm{z}}\right) \sum_{\mathrm{i}=1}^{\mathrm{n}}(\mathrm{n}+1-\mathrm{i}) \mathrm{y}$

Where $\mathrm{G}=$ Gini Ratio

$\mathrm{y}=$ the income of the respondents

$\mathrm{n}=$ number of respondents

$\mathrm{Z}=$ the mean income $\left({ }^{\Sigma} \mathrm{y} / \mathrm{n}\right)$

\section{Economic viability/ profitability}

For any development programme it is worthwhile to examine the economic viability/feasibility/profitability in order to assess the impact of the same. In the present situation, the economic feasibility of farm ponds was analyzed by duly employing financial ratios viz; Net present worth (NPW) Benefit-Cost Ratio (BCR), Internal Rate of Return (IRR) and Pay Back Period (PBP) assuming a life of 10 years for each farm pond and the flow of economic benefits are uniform over years as analyzed in Rama Rao 
et al., (2019) and Kumar et al., (2017). The worthiness of the project was evaluated at $12 \%$ discount rate. Initial digging costs and maintenance costs incurred over the life period of farm pond were compiled in the cost computation and incremental incomes generated after farm pond situation compared to before pond situation were considered as total benefits derived from farm ponds. These incremental returns/ additional returns were a result of a combination of changes in cropping pattern, crop productivities, cropping intensity, Crop Diversification Index and additional area brought into cultivation (Rama Rao et al., 2019).

The formulae used for the financial analysis were:

Net Present Worth (NPW)=Sum of (Present worth of Benefit-Present worth of cost) for all years

$\mathrm{NPW}=\sum_{\mathrm{t}=1}^{\mathrm{n}} \frac{\mathrm{B}_{\mathrm{t}}-\mathrm{C}_{\mathrm{t}}}{(1+\mathrm{r})^{\mathrm{n}}}$

Where $B t=$ Benefits in ' $t$ 'th year

$\mathrm{Ct}=$ Costs in ' $\mathrm{t}$ 'th year

$\mathrm{n}=$ Lifespan of the farm pond

$r=$ rate of interest $(12 \%)$

$(1+r) n=$ discounting factor

Discounted Benefit cost ratio:

$\mathrm{BCR}=\sum_{\mathrm{t}=1}^{\mathrm{n}} \frac{\mathrm{B}_{\mathrm{t}}}{(1+\mathrm{r})^{\mathrm{n}}} / \frac{\mathrm{C}_{\mathrm{t}}}{(1+\mathrm{r})^{\mathrm{n}}}$

\section{Internal rate of return}

It is calculated by discounting the costs and benefits of a project at a progressively higher discount rate till the NPW becomes negative. Thereafter, discount factor at which NPW becomes 'zero' is calculated by mathematical computation which is the IRR of the project. The project with the highest IRR would be considered the best and be undertaken first. This can be done by trial-and-error method. IRR is sometimes referred to as 'economic rate of return' or 'discounted cash flow of return'.

IRR is a point where $\sum_{t=1}^{n} \frac{B_{t}-C_{t}}{(1+r)^{n}}=0$

IRR can be estimated through interpolation method as follows:

$\mathrm{IRR}=$

Lower discount rate + Difference between two discount rates

$\left[\frac{\mathrm{NPW} \text { at lower discount rate }}{\text { Absolute difference between two NPWs at two discount rates }}\right]$

Pay Back period $=$ (Initial investment + maintenance cost) / Net annual cash inflows

\section{Results and Discussion}

The data collected from the farm pond households at two periods i.e. before and after farm pond situations were analyzed as per the objectives and discussed in the subsequent paras.

Average size of land holding is an indicator of agricultural economy. It provides the basis for judging whether a holding is viable enough not merely from point of view of cultivation but also to some extent whether the produce come from there would be adequate for sustenance of operational holder. In the present study the average size of land holding is 2.06 acres. The average cultivated area before farm pond situation was 2.51 acres both in kharif and rabi seasons. With the introduction of PMKSY-watersheds in the study region, a series of farm ponds were constructed in farm fields and the beneficiaries started judicious use of farm pond water from different cultivation 
operations and more over farmers initiated the growing of horticultural crops like cashew, pomegranate, guava etc., on embankments in order to earn higher sustainable income, due to the infrastructure facilities created in the watershed area through capacity building, onfarm trials, demonstrations etc.,

Owing to the initiation of developmental activities in the project area, the farmers slowly realized the importance of high value crops and started cultivating high value crops duly adopting the recommended technology and replacing the traditional crop areas with available farm pond water in addition to rainwater. Thus, there was a change in the cropping pattern, cropping intensity and returns among the households with farm ponds which is presented in Table-1.

It is evident in the project zone that there was an increase in the cultivated area leading to additional cropping intensity $(0.34 \%)$ and incomes among the households. The additional benefit cost ratio was 0.84 which indicates the additional returns to the extent of Rs.0.84/- for one-rupee extra investment. Similarly, the productivities of different crops also enhanced.

The analysis of impact of farm pond activities realized the higher cropping intensity because of crop diversification compared to before farm pond situation. The Crop Diversification Index generally increases with the decrease in concentration and increases with the number of crops. In the project area, the CDI was higher in the case of post farm pond period (0.31) than the pre farm pond (0.28) confirming farm pond help diversification in crop and farm activities.

Almost all the crops recorded increase in yield levels in post-project period over the pre farm pond situation due to the proper utilization of available water. In case of rice yield levels have increased from 15.07 q/acre in pre-project to $25.06 \mathrm{q} / \mathrm{acre}$ in post farm pond. Almost all the crops have registered enhanced yields by two folds due to initiation of farm ponds in the project area (Table-2).

Another important benefit derived or significant change noticed in the study area is cultivable area under crops increased and cropping pattern also changed on increased irrigation facilities. During the pre-farm pond situation as shown in Table-3 major portion of area was under paddy crop with $49.8 \%$ share in total cropped area followed by pulses $(19.11 \%)$, ragi $(13.6 \%)$, maize $(8.5 \%)$, red gram $(3.8 \%)$ and horticulture crops (5.2\%) where as in post farm pond period the respective crops share in paddy and pulses declined marginally and the levels of other crop yields increased considerably. The calculated crop diversification index i.e., Herfindahl Index has declined from 0.31 to 0.28 in pre to post farm pond situation which explains that the crop concentration has declined due to the increased irrigation facilities particularly area diversified to ragi, red gram and horticulture crops from traditional crops.

It is clear that in due course of time we may expect the increase in the ratio of high value crops and reduction in traditional crops in the project area because of PMKSY-Watershed interventions, thus magnitude or degree of diversification may further be reduced this lessen their risks by reaping at least some crops in event of bad weather also.

\section{Pattern on income distribution}

The current study on farm ponds assessment for achieving the goal of sustainable agriculture at farm level explored inequality of incomes among the selected respondents during pre and post project implementation of farm ponds. The findings of the study reveal 
existence of income inequality in the study periods at different degrees.

An examination of Table-4 (Graph) reveals that during pre-farm pond situation, less than $40 \%$ of the total income was concentrated among $63 \%$ of the selected households, however this has been reduced to $55 \%$ after farm pond period thus $8 \%$ of the households shifted to higher income groups i.e., $>40 \%$.

Similarly around $37 \%$ of the households which were in $>40 \%$ income group before farm pond construction switched to further higher income groups due to the infrastructure facilities generated by PMKSY-watershed staff in the project area leading to changes in cropping pattern thus realizing the additional benefits which shows the incomes are not concentrated at one point but distributed among the households during the project period.

This is further confirmed by a Lorenz Curve, generated by plotting the cumulative total income of the households on a vertical axis and on the individual percentile on the horizontal axis, a straight 45-degree line represents total equality (Fig. 1). The comparative analysis of shape of the Lorenzcurve showed a reduction in post project situation compared to pre-project situation. The total income inequality has reduced significantly in post-farm pond with Ginicoefficient value of 0.22 from 0.31 in prefarm pond situation in the study area. The analysis of income distribution infers that in post-farm pond period annual average net income of the household has increased by three folds to Rs.59,369/- from Rs.16,586/- in before farm pond situations. The statistical analysis further confirmed the significant change in the pattern of distribution of total income with higher standard deviation (Rs.25,567/-) and low coefficient of variance (4.30) in post farm pond compared to the pre- farm pond situation. Where the standard deviation and variance were Rs.10,184/- and 61.40 respectively and were not significant statistically. The high CV among the pre form pond group is supported by a high range between the maximum and minimum values of deviation.

Thus, the post Gini coefficient value showed existence of un-skewed distribution of total incomes i.e., incomes are not concentrated at a particular group but distributed among the selected households in the project area.

\section{Economic viability / investment feasibility}

In order to evaluate the economic profitabilitylfinancial feasibility of the farm ponds, the NPW, BCR, IRR and PBP were analyzed assuming a life span of 10 years discounted at $12 \%$ rate of interest. The estimates of investment feasibility analysis indicated the viability of investment on the farm pond in the study area (Table-5). The discounted benefit-cost ratio worked out to more than one i.e., 1.12, implying that the incremental returns to investment due to farm pond activities are feasible. Similarly, the NPW was higher, positive and more than one i.e., Rs.27,56,770/- for all the farm ponds. This implies that the benefits from the farm pond development are higher than the average cost of investment in the farm pond.

Further, the IRR was calculated to 38 which are higher than the loan interest rate by commercial banks, indicating the worthiness of the Government investment on farm pond construction. The payback period would be four (4) years which indicates that the amount invested on farm pond digging will be repaid within four (4) years' time period. Thus, from the results it could be comfortably concluded that the investment in the construction of farm ponds in watershed areas of Srikakulam district of Andhra Pradesh which are used for 
different purposes was economically viable and financially feasible. The calculated financial ratios will be more if intangible benefits derived from the farm pond are quantified and the use of water during the season is also considered. These results are in accordance with the studies conducted by Panda (2009) and Rama Rao et al., (2019) wherein they reported economic viability of investment in construction of farm ponds. Hence, it is suggested to encourage the farmers to go for construction of farm ponds depending upon their land holding and requirement of water for different purposes and to earn sustainable additional income.

The farm ponds in the project area found to impact recharge of ground water not only in the owners borewells but also in the neighboring farmers borewells and enhanced the access to irrigation leading to digging of seven (7) additional bore wells after the farm pond construction. Whereas, there were only three (3) borewells in Tarlakota PMKSYWatershed area before farm pond construction.

Table.1 Farming Economics of the farm pond Households at Pre and Post periods

\begin{tabular}{rlrrr}
\hline S.No. & \multicolumn{1}{c}{ Particulars } & Before farm pond & \multicolumn{1}{c}{$\begin{array}{c}\text { After farm } \\
\text { pond }\end{array}$} & $\begin{array}{c}\text { Incremental } \\
\text { difference }\end{array}$ \\
\hline 1 & Average cultivated area (ac) & 2.51 & 3.21 & 0.70 \\
\hline 2 & Cropping Intensity (\%) & 1.22 & 1.56 & 0.34 \\
\hline 3 & Cost of cultivation/ acre (Rs.) & 6054.35 & 9575.27 & 3520.92 \\
\hline 4 & Gross income/ acre (Rs.) & 12670.50 & 28070.26 & 15399.76 \\
\hline 5 & Net income/ acre (Rs.) & 6616.15 & 18494.98 & 11878.83 \\
\hline$* 6$ & Benefit-cost ratio & 1.09 & 1.93 & 0.84 \\
\hline 7 & Number of bore wells & 3 & 10 & 7 \\
\hline$* 8$ & Gross income/ household (Rs.) & 31762.94 & 90105.52 & 58342.58 \\
\hline$* 9$ & Net income/ household (Rs.) & 16585.64 & 59368.89 & 42783.25 \\
\hline 10 & Average size of holding (ac) & 2.06 & & \\
\hline * Significance @ 5\% level of probability & & & \\
\hline
\end{tabular}


Table.2 Average of different crops yield at two periods (q/ac)

\begin{tabular}{|clrrrr|}
\hline S.No. & Crop & Pre-Farm pond & Post-Farm pond & Difference & \% Difference \\
\hline 1 & Paddy & 15.07 & 25.06 & 9.99 & 66.29 \\
\hline$* 2$ & Pulses & 1.45 & 3.01 & 1.56 & 107.59 \\
\hline$* 3$ & Ragi & 1.40 & 2.71 & 1.31 & 93.57 \\
\hline$* 4$ & Maize & 3.45 & 7.03 & 3.58 & 103.77 \\
\hline 5 & Redgram & 0.65 & 1.10 & 0.45 & 69.23 \\
\hline 6 & Horticulture & 1.77 & 1.86 & 0.09 & 5.08 \\
\hline
\end{tabular}

Table.3 Share of different crops in the project area

\begin{tabular}{|llrrrr|}
\hline S.No. & Name of the crop & \multicolumn{2}{c}{ Cropped area (acres) } & \multicolumn{2}{c|}{ Ratio of each crop (\%) } \\
\hline & & \multicolumn{1}{c}{ Before } & \multicolumn{1}{c|}{ After } & \multicolumn{1}{c|}{ Before } & \multicolumn{1}{c|}{ After } \\
\hline 1 & Paddy & 47.40 & 57.15 & 0.498 & 0.462 \\
\hline 2 & Pulses & 18.22 & 23.33 & 0.191 & 0.189 \\
\hline 3 & Ragi & 12.96 & 20.25 & 0.136 & 0.164 \\
\hline 4 & Maize & 8.08 & 11.96 & 0.085 & 0.097 \\
\hline 5 & Redgram & 3.58 & 4.24 & 0.038 & 0.033 \\
\hline 6 & Horticulture & 5.05 & 6.83 & 0.052 & 0.055 \\
\hline & Total & 95.26 & 123.76 & 1.00 & 1.00 \\
\hline
\end{tabular}


Int.J.Curr.Microbiol.App.Sci (2020) 9(12): 1719-1729

Table.4 Income inequalities in the study area (\%)

\begin{tabular}{|llrr|}
\hline S.No. & Income groups & Pre Project-Income & Post Project Income \\
\hline 1 & $<20 \%$ & 36.84 & 31.58 \\
\hline 2 & $21 \%$ to $40 \%$ & 26.32 & 23.68 \\
\hline 3 & $41 \%$ to $60 \%$ & 15.79 & 18.42 \\
\hline 4 & $61 \%$ to $80 \%$ & 13.16 & 15.79 \\
\hline 5 & $>80 \%$ & 7.89 & 10.53 \\
\hline & Total & 100.00 & 100.00 \\
\hline
\end{tabular}

Table.5 Values of different financial returns

\begin{tabular}{|llr|}
\hline S.No. & \multicolumn{1}{c}{ Details } & \multicolumn{1}{c}{ Financial Investment } \\
\hline 1 & Net present worth & Rs. 27,56,770/- \\
\hline 2 & Internal Rate of Return & $38 \%$ \\
\hline 3 & Discounted Benefit cost ratio & 1.12 \\
\hline 4 & Pay Back period & 4 years \\
\hline
\end{tabular}

Graph for Table 4

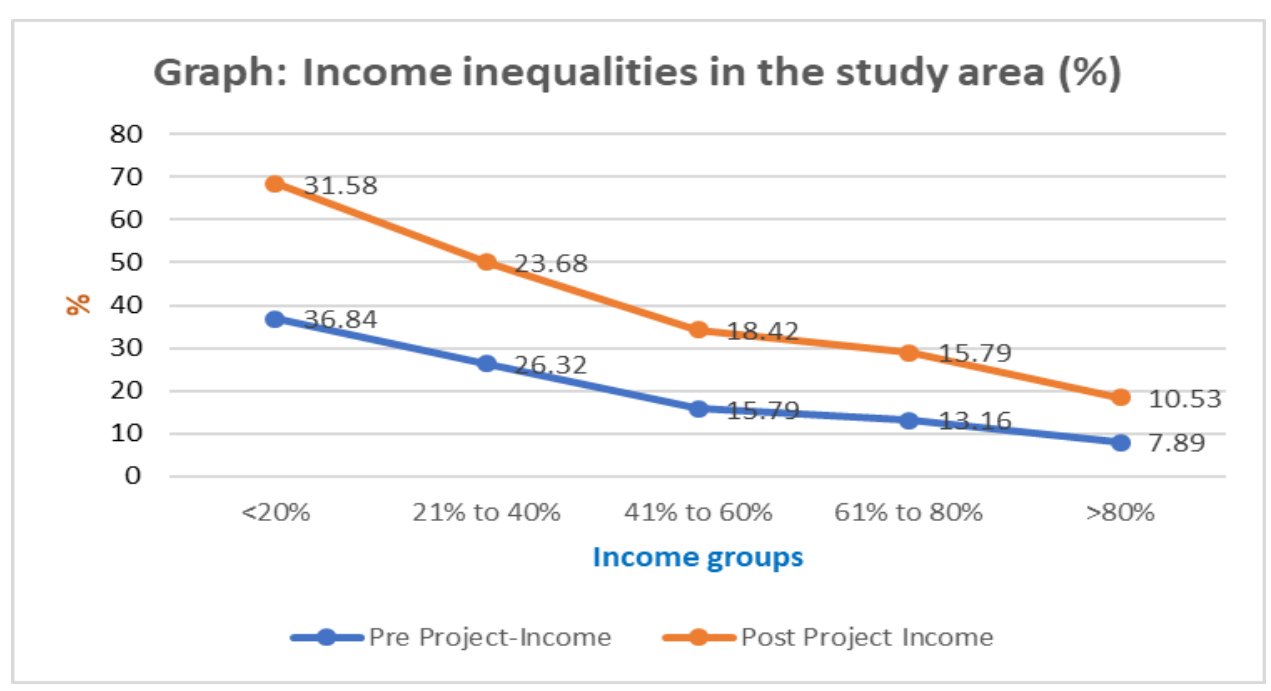


Fig.1 Lorenz curves indicating Income inequalities in pre \& post farm pond situations

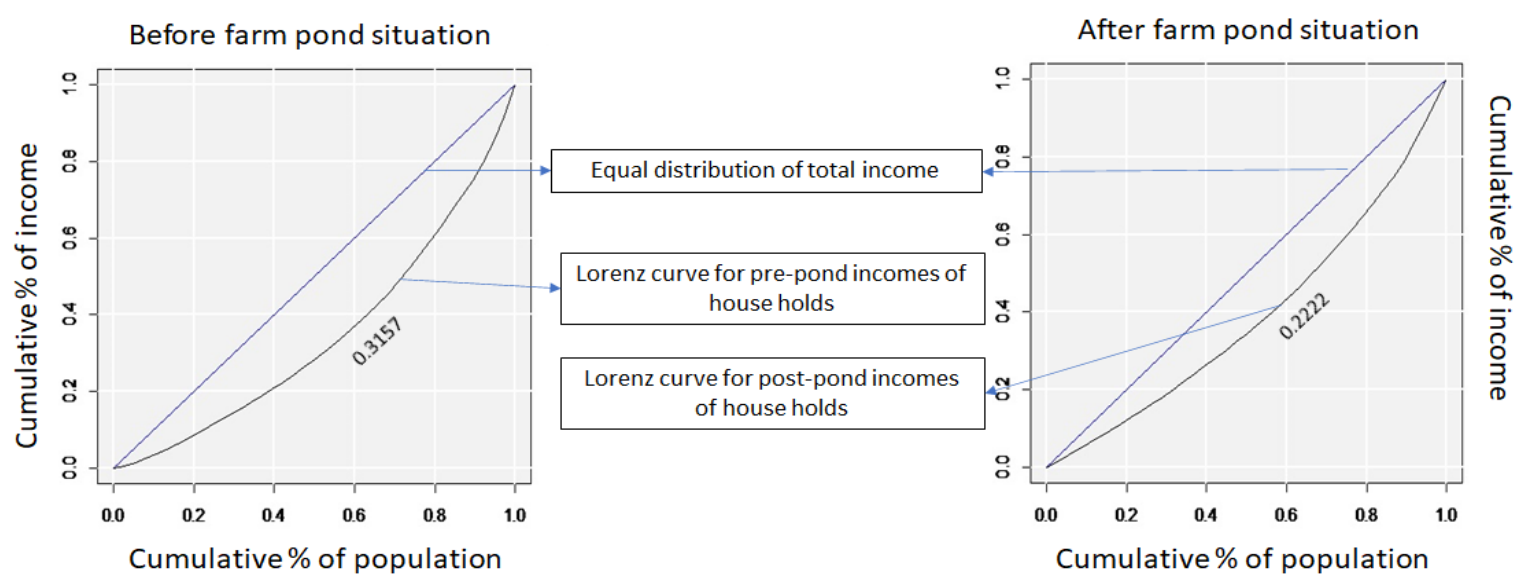

\section{Policy implications}

- Create awareness among farm pond holding farmers about judicious use of farm pond water for different purposes through capacity building activity

- Encourage cultivation of horticulture crops on embankments so that higher sustainable incremental income may be made available to the farm families.

- Guide the farming community in optional crop planning i.e., replacing traditional crops with more remunerative crops

- Farm pond activities should be ensured to make the programme more participating, interactive and cost effective specially to small and medium farmer categories.

- Need for upscaling the success of farm ponds is very essential in order to doubling the farmers income through exposure visits, regional workshops, demonstrations etc.,

- Converge the PMKSY-Watershed program with National Rural Employment Guarantee Scheme (NREGS)

\section{References}

Gini C., (1912), Variabalita e Mutabilita, Bologna, Italy.
Gowri, M.U. and Shanmugam, T. R (2017) Measurement and Sources of Income Inequality among Rural and urban Households in Tamil Nadu, Int. J.Pure App. Bio Sci. 5(2): 621-633

Kumar R., I Sekar, G.K. Jha, D.R. Singh and Kumar, R.R. (2017), "Impact of Decentralized Rainwater Harvesting on Farm income, Variable Input usage and Livestock Possession in Semi-arid Tracts of India; Regression Analysis", Indian Journal of Economics and Development, Vol 13 PP 99-106.

Lorenz, M.O. (1905), Methods of measuring the concentration of Wealth, American Statistical Association, New Series, No. 70.

Palanisami K et al., (2010), In proceedings of National Workshop - cum - Brain Storming on Rainwater Harvesting and reuse through farm ponds: Experiences, Issues and strategies, ICAR-CRIDA and ICRISAT, Hyderabad.

Panda S N (2009) Optimum sizing of on-farm reservoir for various cropping system in rainfed uplands of Eastern India. Proceedings of National Workshop cum brain storming, Central Research Institute for Dry Land Agriculture, 
Hyderabad. Pp. 60-66.

Rama Rao, C A et al., (2019), Levels and Determinants of Economic Viability of Rainwater Harvesting Farm ponds, Indian Journal of Agricultural Economics, Vol. 74, No. 4, Oct-Dec. 2019.

Rao, K V et al., (2010). In proceedings of National Workshop - cum - Brain Storming on Rainwater Harvesting and reuse through farm ponds: Experiences, Issues and strategies, ICAR-CRIDA and ICRISAT, Hyderabad.

Shankar, M. A. and Shiva Kumar, H. R. (2005). Sustainable cropping systems for the Deccan Plateau, Symposium on sustainable agriculture for dry land on the Deccan Plateau, knowledge for application, Bangalore, Pp. 214-222.

\section{How to cite this article:}

Reddy, P.V.R.M., M. Girija Shankar, B. Janardhan Reddy, Y. Shankar Naik, Yerra Eswara Prasad and Rekha, D.V.S.R.L. 2020. Farm Pond Impact Analysis of PMKSY-Watersheds Project in Srikakulam District of Andhra Pradesh. Int.J.Curr.Microbiol.App.Sci. 9(12): 17191729. doi: https://doi.org/10.20546/ijcmas.2020.912.204 